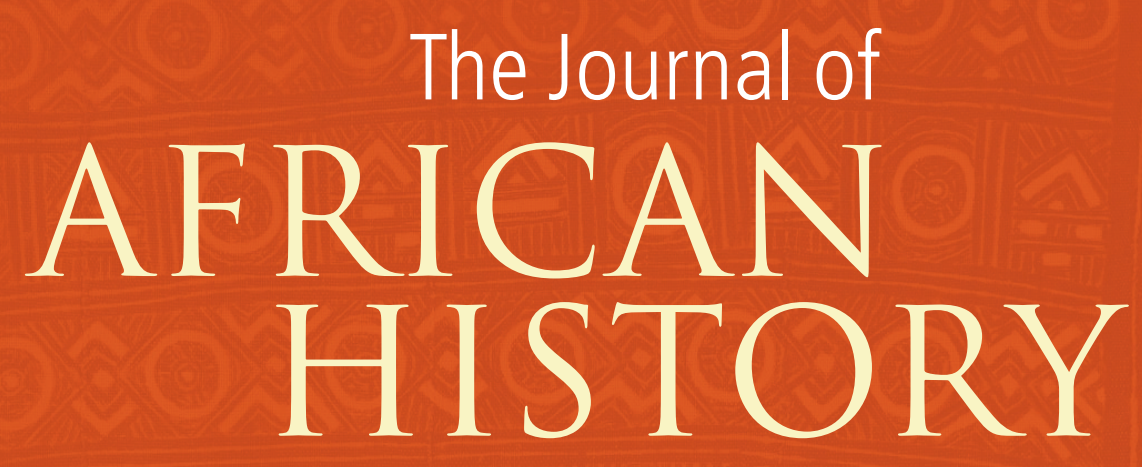

VOLUME $58 \cdot$ NUMBER $1 \cdot 2017$

\title{
CAMbridge
} UNIVERSITY PRESS 


\author{
Editors \\ K. BRECKENRIDGE WISER, University of the \\ Witwatersrand \\ G. MANN Department of History, \\ Columbia University \\ A.D. OSSEO-ASARE History Department, \\ University of Texas at Austin \\ R. REID Department of History, SOAS
}

\section{Reviews Editor}

Books for review should be sent to Abena Dove Osseo-Asare

Book Review Editor

Journal of African History

History Department University of Texas

at Austin

128 Inner Campus Drive

B7000 GAR 1.104

Austin, TX 78712-1739, USA.

jahbooks@austin.utexas.edu

\section{Founding Editors}

J. D. Fage University of Birmingham R. A. Oliver SOAS

\section{Advisory Editorial Board}

J. Allman Washington University in St. Louis

M. Arnoldi Smithsonian Institution

C. A. Babou University of Pennsylvania

D. Branch University of Warwick

B. M. Cooper University of Texas

A. Eckert Humboldt University

T. Falola University of Texas at Austin

L. Fourchard University of Bordeaux

J. B. Gewald Leiden University

D. M. Gordon Bowdoin College

S. E. Greene Cornell University

W. Hawthorne Michigan State University

J. Hyslop Colgate University

N. Kodesh University of Wisconsin

P. Lane Uppsala University

B. Lecocq Humboldt University

L. Lindsay University of North Carolina

H. Médard Université d'Aix-Marseille

H. Mokoena University of the Witwatersrand

M. Moorman Indiana University

N. Musisi University of Toronto

K. Mutongi Williams College

D. Newbury Smith College

S. Reese Northern Arizona University

D. Schoenbrun Northwestern University

R. Stephens Columbia University

L. M. Thomas University of Washington

L. White University of Florida

J. Willis Durham University

\section{SUBSCRIPTIONS}

The Journal of African History (ISSN $002 \mathrm{I}-8537$ ) is published three times a year. Three parts form a volume. The subscription price (excluding VAT) of volume 58, 2017 (which includes print and electronic access) is $£_{296}$ (US \$5 Io in the USA, Canada and Mexico) for institutions; $£ 60$ (US \$IO4 in the USA, Canada and Mexico) for individuals. Students ordering direct from the Press and certifying that the Journal is for their own personal use can subscribe to the print version at $£_{4}$ I (US $\$ 65$ in the USA, Canada and Mexico). The electronic-only price available to institutional subscribers is $£_{25} 8$ (US \$449 in the USA, Canada and Mexico). Single parts $£_{\text {II } 3}$ net (US \$I96 in the USA, Canada and Mexico). Prices include delivery by air where appropriate. EU subscribers (outside the UK) who are not registered for VAT should add VAT at their country's rate. VAT registered subscribers should provide their VAT registration number.

Orders, which must be accompanied by payment, may be sent to a bookseller or to the publisher: Cambridge University Press, Journals Fulfillment Department, UPH, Shaftesbury Road, Cambridge CB2 8BS, UK.; or in the USA, Canada and Mexico, to Cambridge University Press, Journals Fulfillment Department, 1 Liberty Plaza, Floor 20, New York, NY 10006,

USA. Japanese prices for institutions are available from

Kinokuniya Company Ltd., PO Box 55, Chitose,

Tokyo I 56, Japan.

Special arrangements exist for sponsoring individual subscriptions for African scholars, please apply to the publisher for details.

\section{COPYING}

This journal is registered with the Copyright Clearance Center, 222 Rosewood Drive, Danvers, MA I923. Organizations in the USA who are also registered with CCC may therefore copy material (beyond the limits permitted by sections I07 and I08 of US copyright law) subject to payment to CCC of the per-copy fee of $\$$ I 5 . This consent does not extend to multiple copying for promotional or commercial purposes. Code 002 I-8537/20I7 \$ 5 . ISI Tear Sheet Service, 350 I Market Street, Philadelphia, Pennsylvania 19104, USA, is authorized to supply single copies of separate articles for private use only. Organizations authorized by the Copyright Licensing Agency may also copy material subject to the usual conditions.

For all other use, permission should be sought from Cambridge or the American Branch of Cambridge University Press.

Internet Access. This journal is included in Cambridge Core which can be found at cambridge.org. For further information on other Press titles access http://www.cambridge.org/. 
The Journal of

\section{AFRICAN HISTORY}

\section{CONTENTS}

\section{JAH FORUM: E. P. Thompson in African History}

Introduction to the Forum

E. P. Thompson, 'Social History', and South African Historiography, I970-90

Peter Delius University of the Witwatersrand

The Spinning Jenny and the Sorting Table: E. P. Thompson and Workers in Industrializing Europe and Southern Africa

John Higginson University of Massachusetts

Nonconformity in Africa's Cultural History

Derek R. Peterson University of Michigan

Whigs and Hunters: The Path not Taken

Luise White University of Florida

An Ethiopian Catholic in the Early Modern African Diaspora

African Cosmopolitanism in the Early Modern Mediterranean: The Diasporic Life of Yohannes, the Ethiopian Pilgrim who became a Counter-Reformation Bishop

Matteo Salvadore American University of Sharjah

\section{Disputing Political Power in Buganda}

Dreams and Political Imagination in Colonial Buganda

Jonathon L. Earle Centre College, Kentucky

All the Kabaka's Wives: Marital Claims in Buganda's 1953-5 Kabaka Crisis

Carol Summers University of Richmond, Virginia

\section{Surviving Secession in Nigeria}

The Survival Con: Fraud and Forgery in the Republic of Biafra, 1967-70

Samuel Fury Childs Daly Rutgers University, New Brunswick

\section{REVIEWS OF BOOKS}

Charles Becker, Roland Colin, Liliane Daronian, and Claude Hélène Parrot (eds.), Yves Person, un historien de l'Afrique engagé dans son temps 
ii $\operatorname{VOL} .58, \mathrm{NO}$. I

Odile Goerg, Fantômas sous les tropiques: Aller au cinéma en Afrique colonial

Glenn Reynolds, Colonial Cinema in Africa: Origins, Images, Audiences

\section{Ch. Didier Gondola}

Martin A. Klein (ed.), Historical Dictionary of Slavery and Abolition

Jelmer Vos

Hugh Roberts, Berber Government: The Kabyle Polity in Pre-colonial Algeria

Phillip C. Naylor

James C. McCann, The Historical Ecology of Malaria in Ethiopia: Deposing the Spirits

Benjamin J. Reilly

Derek R. Peterson, Ethnic Patriotism and the East African Revival: A History of Dissent,

c. $1935-1972$

\section{Brian Stanley}

Hassan J. Ndzovu, Muslims in Kenyan Politics: Political Involvement, Marginalization, and I 56 Minority Status

\section{Christian Green}

S. H. Fazan. Edited by John Lonsdale, Colonial Kenya Observed: British Rule, Mau Mau and the Wind of Change

\section{Brett Shadle}

Deborah Mayersen, On the Path to Genocide: Armenia and Rwanda Reexamined

Kjell Anderson

Sarah Longair, Cracks in the Dome: Fractured Histories of Empire in the Zanzibar Museum, I6I I897-I964

\section{Antoni Scholtens Folkers}

Ruramisai Charumbira, Imagining a Nation: History and Memory in Making Zimbabwe

\section{Alois S. Mlambo}

Joost Fontein, Remaking Mutirikwi: Landscape, Water and Belonging in

Southern Zimbabwe

\section{Andrew M. C. Hartnack}

Saul Dubow, Apartheid, I948-1994

\section{Nancy L. Clark}

Shannen L. Hill, Biko's Ghost: The Iconography of Black Consciousness

\section{Daniel Magaziner}

Catie Gressier, At Home in the Okavango: White Batswana Narratives of Emplacement and Belonging

\section{David McDermott Hughes}

Luise White, Unpopular Sovereignty: Rhodesian Independence and African Decolonization

\section{Timothy Scarnecchia}


Roquinaldo Ferreira, Cross-Cultural Exchange in the Atlantic World: Angola and Brazil

during the Era of the Slave Trade

\section{Stefania Capone}

Todd Cleveland, Diamonds in the Rough: Corporate Paternalism and African

Professionalism on the Mines of Colonial Angola, 1917-1975

\section{Jeremy Ball}

Christine Hatzky, Cubans in Angola: South-South Cooperation and Transfer of

Knowledge, I976-I99I

\section{Myra Ann Houser}

Aissata Kane Lo, De la Signare à la Diriyanké sénégalaise: Trajectoires féminines et visions partagées

Philip J. Havik

Saheed Aderinto (ed.), Children and Childhood in Colonial Nigerian Histories

Rufus T. Akinyele

Meera Venkatachalam, Slavery, Memory, and Religion in Southeastern Ghana,

c. $1850-$ Present

\section{Judy Rosenthal}

\section{CORRIGENDUM}

A New Type of Citizen: Youth, Gender, and Generation in the Ghanaian Builders Brigade Corrigendum 